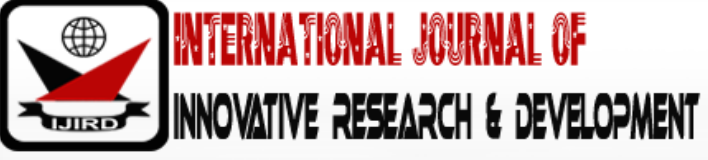

ISSN 2278 - 0211 (Online)

\section{Principals' Instructional Leadership and Students' Academic Achievement in Public Secondary Schools in Makueni Sub-County, Kenya}

\author{
Muteti Catherine Mueni \\ Lecturer, Department of Postgraduate Studies, Faculty of Education, \\ Mwenge Catholic University, Tanzania
}

\begin{abstract}
:
School principals as instructional leaders have the essential responsibility of ensuring that quality teaching and learning occurs in schools. The study examined principals' instructional leadership, and its relationship to students' academic achievement in public secondary schools in Makueni Sub-County in Kenya. The study adopted cross sectional survey design. The study targeted all public secondary schools in Makueni Sub-County. The sample size comprised of 147 students drawn from 15 public secondary schools. All the 15 principals from the selected schools participated in the study. Data was collected through a structured, self-administered questionnaire, interview schedule and document analysis schedule. Data were analysed using Statistical Package for Social Scientists (SPSS) ver.20. Pearson's ProductMoment Correlation Coefficient was used to establish the significance of relationships. It is concluded that principals' instructional leadership positively affects students' academic performance; Students' academic achievement to a large extent is determined by the instructional leadership executed by the principals, through provision of teaching and learning resources, establishing policies for monitoring students' progress and ensuring good time management; there is a fairly strong and positive relationship between students perceptions on principals instructional leadership and academic performance. Thus, students' perceptions towards principals' instructional leadership influence their academic performance. Therefore, principals should perform their instructional leadership functions as required of them to influence students' academic performance.
\end{abstract}

Keywords: Instructional leadership, academic performance

\section{Introduction}

The fundamental aim of a learning institution is to provide quality education to its students. This is done by imparting knowledge, skills, attitudes and values. This can be attained through effective instructional leadership role performance by secondary schools' principals. According to Jones (2010), instructional leadership must reside with a team of leaders of which the principal serves as the leader of leaders. The Government of Kenya has thusentrusted school principals with the overall responsibility of managing, controlling and the maintenance of educational standards in the school as specified in the Education Act of 2012. The Education Act recognises the school principal as the custodian of all instructional programmes and other activities in the school, hence accountable for all that happens in the school. In particular, the school principal has to employ educational leadership that creates an environment which is supportive to students learning and that monitors the academic achievement of the students. Similarly, the Teachers Service Commission (TSC) code of regulations for teachers (GoK, 2006) underscores the roles of the school principal as those of instructional leadership. Therefore, secondary school principals have the obligatory responsibility of providing direction to teachers and the students on instructional issues. Efforts should thus be made to improve the conditions which surround learning and growth of students.

According to Blasé and Blasé (2000) instructional leadership is specific behaviour such as making suggestions, giving feedback, modelling instruction, soliciting opinion, supporting collaboration, providing professional development opportunities and giving praise for effective teaching. Blasé and Blasé further describe an instructional leader as one who makes instructional quality the top priority of the school and attempts to ensure that the vision of the school is realised. Marks and Printy (2003) reconceptualise the term "instructional leadership" to replace the hierarchical and procedural notion with the concept of "shared" instructional community support. Oyetunyi (2006) portrays principal's instructional leadership to be of importance when reflecting on aspects of instructional practices, academic achievement, and students' discipline. Fullan (2010) shares a similar opinion as Oyetunyi (2006) when he clearly articulates the role of the school principal as an instructional leader to be the most essential job in the education system. For Mbiti (2009), the success of any school depends on how effective the head teacher is as an administrator. 
Therefore, principals' instructional leadership is a significant factor in facilitating and improving the academic achievement of the students. Students' learning should hence be the top priority for the any school principal. Every other activity in the school should revolve around the enhancement of students' learning. Consequently, school principals should give the best of their ability in facilitating the realisation of the school's desired academic achievement.

\section{Statement of the Problem}

The responsibility of improving instruction and learning rests in the hands of the school principal. This has been derived from the TSC code of regulations (2006) and from the Education Act of 2012. The school principal has the responsibility of ensuring instructional leadership that enhances students' academic performance. The study concern was to assess principals' instructional leadership and its relationship with students' academic achievement in selected public secondary schools in Makueni Sub-County, Kenya. Reviewed studies on instructional leadership give the general focus of principals as instructional leaders to be on provision of teaching and learning resources, supervising classroom instructions and provision of professional development programmes. However, the studies do not adequately show how principals instructional relate to students' academic achievement. Therefore, this study examined the relationship that exist between principals' instructional leadership, and students' academic performance in some selected secondary schools in Makueni Sub-County.

\section{Research Questions}

The study was guided by the following research questions:

What is the students' perception towards principals' instructional leadership?

Is there a relationship between students' perception of principals' instructional leadership and academic achievement?

What challenges do principals encounter as instructional leaders?

What strategies should be put in place to enhance principals' instructional leadership, and students' academic achievement?

For the purpose of establishing the relationship between instructional leadership, and students' academic achievement, the following research hypothesis was tested.

HA: There is a significant relationship between the students' perceptions mean scores and academic mean scores for all the fifteen schools for the year 2014.

\section{Significance of the Study}

The study is important for the following reasons:

The study will help the Ministry of Education to know the actual status of principal's instructional leadership, in relation to students' academic achievement in public secondary schools. It is anticipated that knowledge derived from this study will help school principals to identify areas to pay attention to in order to improve students' academic achievement. Furthermore, the knowledge obtained from the study will add information to the existing knowledge on instructional leadership, and students' academic achievement hence creating a data bank for further research.

\section{Scope and Delimitation of the Study}

The study was carried out in some selected secondary schools Makueni Sub-County of Makueni County, Kenya. These schools are comparable to other schools in counties bearing identical academic, socio-economic and geographical characteristics as Makueni Sub-County. Moreover, public secondary schools have similar guidelines on matters of administration and the running of schools.

\section{Literature Review}

Various studies have been reviewed on principals' instructional leadership and students' academic achievement. Among the studies are as follows: Academic achievement is influenced by the extent to which the head teacher performs instructional supervision duties as revealed through a study by Kimosop (2002) in Kabarnet and Salawa Divisions of Baringo Sub-County. The study sought to find out how the head teachers performed their instructional supervisory duties. Using the descriptive survey technique, the researcher obtained a randomly selected sample of six schools. All head teachers and heads of departments were purposively sampled for the purpose of the study. The instruments used for the data collection were questionnaires, interview schedules and observation schedules. The research findings showed that most head teachers were not performing their instructional supervisory duties for example classroom observations, checking students' notes and teaching notes frequently. These functions in most schools were left to the heads of departments. As a result, schools where the head teachers did minimal instructional supervision duties had inadequate learning resources. The findings by Kimosop (2002) could reflect the situation in other Sub-Counties in the country where principals are not keen in supervising instructions.

Keter (2002) carried out research in Nandi aimed at examining the extent to which the administrative challenges faced by secondary school head teachers hinder them from carrying out their duties of championing curriculum development in their schools. The researcher used the survey design in this study. Three sets of questionnaires were used for data collection. Data was analysed using frequencies, percentages, mean scores and tabulation. The study revealed that head teachers had difficulty in performing their curriculum duties and as a result some schools did not have enough textbooks and students were forced to share textbooks which de-motivated both teachers and students hence leading to poor performance. The study by Keter (2002) exposes the frustrations students and teachers experience due to lack of textbooks. 
Momanyi (2003) sought to find roles played by principals as instructional leaders in relation to students' academic achievement in Kisii Central District. The researcher used the survey design. The target population consisted of all principals, teachers and students in both private and secondary schools in Kisii Central District. Instrument for data collection were questionnaires, observation guide, document analysis and interview guide. The findings of the study show that head teachers of all schools provided class timetables and master timetables. Subjects were allocated periods as recommended in the curriculum. However, school time was not used effectively. Time wastage was rampant is such areas like co-curricular activities; long assembly, coming late to school and over testing among others. The researcher also noted that principals were not role models in time keeping. Principals as instructional supervisors in their respective schools should ensure that time is well managed so as for the school to attain its core objectives that is teaching and learning.

A study by Mutune (2005) investigated head teachers' performance of their roles as instructional leaders in Nakuru Private Catholic Secondary Schools. The study adopted a quantitative approach in which questionnaires for students, teachers and interview schedule for head teachers were used for data collection. Data were analysed using descriptive statistics. The findings of the study were that majority of the teachers and students viewed provision of teaching and learning materials and communication channels as the most important functions of instructional leaders. Institutional leadership modelling was rarely practiced by head teachers. The study further found that, instructional leadership was limited by high teachers turn over, outside interference, lack of school funds and inadequate teaching learning resources. Other limitations included weak administrative skills from the head teachers. The findings by Mutune (2005) confirm that principals were performing their instructional leadership roles by providing teaching and learning materials and had well designed channels of communication. However, the findings of the study did not explain whether the roles performed by the principal, for instance provision of teaching and learning resources, increased teachers' belief that they had the ability to influence change in students' academic achievement.

Baffour-awuah (2011) carried out a study on supervision of instruction in public primary schools in Ghana: teachers' and head teachers' perspectives. The main purpose of the study was to better understand the practice of instructional supervision in the schools by examining teachers' and head teachers' perspectives about how they experienced and conceptualised instructional supervision. The study also sought to uncover aspects of instructional supervision that teachers and head teachers think should be practiced. A mixed method approach was employed to collect data from multiple sources including questionnaires, interviews, and policy documents on instructional supervision. A municipal education district in Ghana was selected for the study. The study found that the GES policy document on instructional supervision emphasised aspects of instructional supervision that related to monitoring teaching activities and ensuring maximum use of instructional time. Teachers and head teachers in this study practised, experienced and conceptualised instructional supervision which comprised mainly "traditional" aspects.

Reche, Bundi, Riungu and Mbugua (2012) carried out a study that sought to investigate factors that contribute to poor performance in Kenya Certificate of Primary Education examination in public day primary schools in Mwimbi Division, Maara District, Kenya. Descriptive survey design was used to obtain the sample. The study identified that the following as factors contributing to poor performance in primary national examination; inadequate learning resources, inadequate monitoring by head teachers, understaffing, high teacher turnover rate, inadequate prior preparation, lack of motivation for teachers, large workload, absenteeism by both teachers and pupils, pupil's lateness, lack of support from parents. From the findings, head teachers were not performing their instructional leadership roles as was expected of them. This translated to poor performance in national examinations.

Mavindu (2013) carried out a study that sought to determine the influence of principal's instructional supervision practices on students' KCSE performance in Trans-Mara West district. Four research objectives were used to investigate the extent to which the principals in Trans- Mara West district undertook clinical supervision: classroom visitation, teacher observation, post observation conference and the extent to which teachers' professional records are checked by principals. The researcher used descriptive survey design. Two sets of questionnaires were administered; one for principals and the other one for teachers. The study revealed that principals checked teachers' records of work and ensured adherence to the timetable. Observing teachers when teaching recorded low. The study by Mavindu (2013) focused on principal's instructional supervision practices on students' performance.

From the reviewed literature, it is evident that principal's instructional leadership influences students' academic achievement. However, most of the reviewed studies do not explain the relationship between principal's instructional leadership and students' academic achievement, which was a major concern in this study.

\section{Methodology}

Cross sectional survey design was used. The design was preferred because it allows large amount of data to be collected for a short period of time and from a variety of people. Besides, it allows the researcher to examine the characteristics of a sample such as the attitude, preference and interests. Furthermore, cross-sectional survey design allows generalisation of findings to the wider population. The study was conducted in 15 Secondary Schools among 34 Secondary Schools in Makueni Sub-County. All the 15 principals from the selected schools and the form three and form four students formed the study respondents.

\section{Data Collection Instruments}

The researchers used questionnaires, structured interview schedule and document analysis schedule to collect data from the participants. 


\section{Findings}

The study was guided by three research questions and one hypothesis.

Research Question 1: Students' Perceptions on Principals Instructional Leadership

The first research question sought to investigate the perceptions of students towards principals' instructional leadership. Students perceptions on instructional leadership of their principals were rated $5=$ strongly agree, $4=$ agree, 3 $=$ undecided, 2 =disagree and 1 =strongly disagree. For the negative statements it was the opposite, $1=$ strongly agree, $2=$ agree, 3 =undecided, 4 = disagree and $5=$ strongly disagree. Statistical Package for Social Sciences (SPSS, version 20.0)was used to compute the perception mean scores. The researcher had sampled 15 schools for this study. The sampled schools were randomly assigned letter codes A, B up to letter P. From each of these schools, students were selected to participate in the study. The perception for each student was calculated in such a way that each individual student had a perception mean score. For example, in school A, nine students participated in the study. Each of these student's perception mean score was calculated. Then the researcher computed the perception mean scores for all the nine students to obtain a general mean score for school A. Similar approach was used in calculating the perception mean score for each student in each respective school. As well, the same approach was employed in computing the students' general perception mean scores in all the 15 schools. Table 1 summarises the findings.

\begin{tabular}{|c|c|c|c|}
\hline $\begin{array}{c}\text { School Pseudo } \\
\text { Name }\end{array}$ & & School Mean Score & $\begin{array}{c}\text { Principal Instructional } \\
\text { Leadership }\end{array}$ \\
\hline \multirow[t]{3}{*}{$\mathrm{A}$} & Mean & 3.2040 & 2.7989 \\
\hline & $\mathrm{N}$ & 9 & 9 \\
\hline & Std. Deviation & .00000 & .29616 \\
\hline \multirow[t]{3}{*}{$\mathrm{B}$} & Mean & 4.0100 & 2.9660 \\
\hline & $\mathrm{N}$ & 10 & 10 \\
\hline & Std. Deviation & .00000 & .46469 \\
\hline \multirow[t]{3}{*}{$\mathrm{C}$} & Mean & 5.4020 & 2.8689 \\
\hline & $\mathrm{N}$ & 9 & 9 \\
\hline & Std. Deviation & .00000 & .59261 \\
\hline \multirow[t]{3}{*}{$\mathrm{D}$} & Mean & 4.3160 & 3.0933 \\
\hline & $\mathrm{N}$ & 9 & 9 \\
\hline & Std. Deviation & .00000 & .69231 \\
\hline \multirow[t]{3}{*}{$\mathrm{E}$} & Mean & 3.9740 & 2.8730 \\
\hline & $\mathrm{N}$ & 10 & 10 \\
\hline & Std. Deviation & .00000 & .35540 \\
\hline \multirow[t]{3}{*}{$\mathrm{F}$} & Mean & 3.7800 & 3.0211 \\
\hline & $\mathrm{N}$ & 9 & 9 \\
\hline & Std. Deviation & .00000 & .39429 \\
\hline \multirow[t]{3}{*}{$\mathrm{G}$} & Mean & 4.7680 & 3.1622 \\
\hline & $\mathrm{N}$ & 9 & 9 \\
\hline & Std. Deviation & .00000 & .59920 \\
\hline \multirow[t]{3}{*}{$\mathrm{H}$} & Mean & 4.8040 & 2.8730 \\
\hline & $\mathrm{N}$ & 10 & 10 \\
\hline & Std. Deviation & .00000 & .57941 \\
\hline \multirow[t]{3}{*}{$\mathrm{I}$} & Mean & 4.9240 & 3.3233 \\
\hline & $\mathrm{N}$ & 9 & 9 \\
\hline & Std. Deviation & .00000 & .46098 \\
\hline \multirow[t]{3}{*}{$\mathrm{J}$} & Mean & 7.6170 & 3.8855 \\
\hline & $\mathrm{N}$ & 11 & 11 \\
\hline & Std. Deviation & .00000 & .50200 \\
\hline \multirow[t]{3}{*}{$\mathrm{K}$} & Mean & 6.1040 & 3.7692 \\
\hline & $\mathrm{N}$ & 13 & 13 \\
\hline & Std. Deviation & .00000 & .72750 \\
\hline \multirow[t]{3}{*}{$\mathrm{L}$} & Mean & 8.5000 & 4.3450 \\
\hline & $\mathrm{N}$ & 10 & 10 \\
\hline & Std. Deviation & .00000 & .27492 \\
\hline \multirow[t]{3}{*}{$\mathrm{M}$} & Mean & 7.0160 & 3.4550 \\
\hline & $\mathrm{N}$ & 10 & 10 \\
\hline & Std. Deviation & .00000 & .43085 \\
\hline \multirow[t]{3}{*}{$\mathrm{N}$} & Mean & 8.9280 & 3.7440 \\
\hline & $\mathrm{N}$ & 10 & 10 \\
\hline & Std. Deviation & .00000 & .43500 \\
\hline \multirow[t]{2}{*}{$\mathrm{P}$} & Mean & 6.2200 & 3.5356 \\
\hline & $\mathrm{N}$ & 9 & 9 \\
\hline
\end{tabular}




\begin{tabular}{|c|c|c|c|}
\hline $\begin{array}{c}\text { School Pseudo } \\
\text { Name }\end{array}$ & School Mean Score & $\begin{array}{c}\text { Principal Instructional } \\
\text { Leadership }\end{array}$ \\
\hline & Std. Deviation & .00000 & .48136 \\
\hline Total & Mean & 5.6394 & 3.3369 \\
\hline & $\mathrm{N}$ & 147 & 147 \\
\hline & Std. Deviation & 1.71867 & .66240 \\
\hline
\end{tabular}

Table 1: Students' Perceptions on Principals Instructional Leadership

Korb (2003) describes how items in a Likert scale, can be combined so that individuals with the most favourable attitudes will have the highest scores; while individuals with the least favourable (or unfavourable) attitudes will have the lowest scores. Based on the 5-point attitude criteria, 1 is regarded as low attitude (unfavourable score), while 5 as high attitude (favourable score) and 3 as average attitude (Korb, 2003). The researcher in this study applied the views by Korb (2003) to devise a decision rule. The formulated decision rule was used in interpreting the mean scores obtained after computing the general perceptions mean for respondents in each school, that is, negative (for $\mathrm{M}<3$ ), neutral (for $\mathrm{M}=3$ ) and positive (for $\mathrm{M}>3$ ).

The findings in Table 1 show that students had varied perceptions towards their principals' instructional leadership. In nine out of the fifteen schools which participated in this study, students' general perception mean scores were found to be $M>3$. According to the formulated decision rule, the mean scores were interpreted as positive. This implies that students from the nine schools in Makueni Sub-Country had positive perceptions towards their principals' instructional leadership role performance. The positive perceptions expressed by the students suggest that instructional leadership was regarded as an important aspect in facilitating, improving and promoting academic progress of students in the Sub-County. However, the perception mean scores from four schools were found to be $M<3$. These perceptions mean scores were interpreted as negative. This revealed that students from the four schools were not contented with the instructional leadership role performance of their principals. Only in one school students expressed neutral perception towards their principal's instructional leadership $M=3$.

From the findings, majority of the schools in which students expressed positive perceptions towards their principals' instructional leadership had remarkable academic performance. For example, students from school L expressed positive perceptions towards their principal's instructional leadership as explained by a general perception mean score $\mathrm{M}$ =4.34. Equally, the school registered a mean score of 8.50 points in KCSE examination in the year 2014. Furthermore, in school $\mathrm{N}$ students expressed positive perceptions towards their principal's instructional leadership as indicated by a general mean score $\mathrm{M}=3.74$. Similarly, the school had an outstanding mean score of 8.93 points in KCSE examination in the year in question. The positive perceptions expressed by students from high performing schools tend to suggest that school principals have influence on students' academic performance. Through their instructional leadership, school principals inspire students towards positive thinking about the school's leadership. This in turn encourages students to strive towards good academic performance.

On the other hand, in three out of the four schools in which students expressed negative perceptions towards their principal's instructional leadership $\mathrm{M}<3$ had also recorded low students' academic performance. For instance, in school A the students general perceptions mean score was found to be $\mathrm{M}=2.79$, while the KCSE examination mean score for the same school was 3.20 points in the year 2014. As well, in school E the general perceptions mean score was $M=2.87$; while the KCSE examination mean score was found to be 3.97 points. The findings from the four schools reveal a close link between negative perceptions held by students on their principals' instructional leadership and the academic performing in these schools. Thus, when principals fail to inspire students to high academic performance, the outcome is dissatisfaction towards instructional leadership.

The researcher further sought to explore how the students' responded to various items on principals' instructional leadership. The results are presented in Table 2.

\begin{tabular}{|c|c|c|c|c|c|c|c|c|c|c|c|}
\hline \multirow{3}{*}{ Item } & \multicolumn{10}{|c|}{ Response } & \multirow[t]{3}{*}{$\mathbf{M}$} \\
\hline & \multicolumn{2}{|c|}{ SA } & \multicolumn{2}{|c|}{$\mathbf{A}$} & \multicolumn{2}{|c|}{$\mathbf{U}$} & \multicolumn{2}{|c|}{ D } & \multicolumn{2}{|c|}{ SD } & \\
\hline & f & $\%$ & f & $\%$ & f & $\%$ & f & $\%$ & f & $\%$ & \\
\hline $\begin{array}{l}\text { Establishes conducive teaching } \\
\text { and learning environment in the } \\
\text { school }\end{array}$ & 40 & 27.2 & 51 & 34.7 & 18 & 12.2 & 7 & 4.8 & 31 & 21.1 & 3.2 \\
\hline $\begin{array}{c}\text { Provides learning opportunities } \\
\text { for students by organising } \\
\text { academic trips }\end{array}$ & 27 & 18.4 & 19 & 12.9 & 9 & 6.1 & 29 & 19.7 & 63 & 42.9 & 2.4 \\
\hline $\begin{array}{l}\text { Reinforces positive teacher- } \\
\text { student relationship to ensure } \\
\text { quality learning }\end{array}$ & 40 & 27.2 & 51 & 34.7 & 18 & 12.2 & 7 & 4.8 & 31 & 21.1 & 3.4 \\
\hline $\begin{array}{l}\text { Ensures availability of teaching } \\
\text { and learning resources }\end{array}$ & 25 & 17.0 & 21 & 14.3 & 24 & 16.3 & 24 & 16.3 & 53 & 36.1 & 2.6 \\
\hline $\begin{array}{c}\text { Ensures the school has master } \\
\text { timetable at the beginning of } \\
\text { the term }\end{array}$ & 47 & 32.0 & 41 & 27.9 & 19 & 12.9 & 12 & 8.2 & 28 & 19.0 & 3.3 \\
\hline
\end{tabular}




\begin{tabular}{|c|c|c|c|c|c|c|c|c|c|c|c|}
\hline $\begin{array}{c}\text { Ensures all lessons in the } \\
\text { timetable are taught and } \\
\text { monitors use of teaching time }\end{array}$ & 53 & 36.1 & 49 & 33.3 & 21 & 14.3 & 8 & 5.4 & 16 & 10.9 & 3.8 \\
\hline $\begin{array}{c}\text { Ensures school has enough } \\
\text { teachers for each subject }\end{array}$ & 41 & 27.9 & 30 & 20.4 & 15 & 10.2 & 34 & 23.1 & 27 & 18.4 & 3.2 \\
\hline $\begin{array}{c}\text { Establishes policies of } \\
\text { monitoring students' progress }\end{array}$ & 63 & 42.9 & 36 & 24.5 & 11 & 7.5 & 21 & 14.3 & 16 & 10.9 & 3.7 \\
\hline $\begin{array}{c}\text { Communicates to parents on } \\
\text { students' academic progress }\end{array}$ & 81 & 55.1 & 42 & 28.6 & 12 & 8.2 & 6 & 4.1 & 6 & 4.1 & 4.3 \\
\hline $\begin{array}{c}\text { Deals with students' discipline } \\
\text { appropriately }\end{array}$ & 74 & 50.3 & 40 & 27.2 & 4 & 2.7 & 4 & 2.7 & 25 & 17.0 & 3.9 \\
\hline $\begin{array}{c}\text { Ensures teachers cover the } \\
\text { syllabus in good time }\end{array}$ & 32 & 21.8 & 11 & 7.5 & 19 & 12.9 & 51 & 34.7 & 34 & 23.1 & 2.7 \\
\hline
\end{tabular}

Table 2: Students' Perceptions on Principal's Instructional Leadership

The findings in Table 2 showsthat, 55.1\% students stronglyagreed that their principals communicated to their parents about their academic progress during parentsand academic days. While $50.1 \%$ of the students strongly agreed that their principals dealt with students discipline appropriately. Moreover, $42.9 \%$ of the students strongly agreed that their principals ensuredthat their schools had well established policies of monitoring students' academic progress. Thus, the instructional leadership executed by the principals was acceptable to the students and therefore likely to translate into good academic performance in the schools.

However, the study revealed that principals neglected some instructional leadership responsibilities. For instance, $42.9 \%$ of the students strongly disagreed that their principals were providing learning opportunities for students by organising academic trips. Whereas, $36.1 \%$ of the students strongly disagreed that their principals were ensuring availability of teaching and learning resources. Likewise, $23.1 \%$ of the students strongly disagreed that their principals ensured teachers covered the teaching syllabus in good time.

The findings reveal a shortage in teaching and learning resources. The findings further reveal that teachers were not covering their syllabus in good time to allow intensive revision with their students. A situation where teaching and learning resources are lacking would negatively influence the syllabus coverage. A scenario of this kind is described by Keter (2002) in a study as frustrating to both the teachers and the students. Furthermore, lack of syllabus coverage suggests that, school principals were not supervising teaching in their schools. These would indicate that, students in some public secondary schools in Makueni Sub-County sat for their form four KCSE examinations without covering the required content in various subjects'.

In order to get the whole picture of students' perceptions on principals' instructional leadership, an open-ended item from the questionnaire items was included. The question item sought to establish ways in which the principals were enhancing teaching and learning in their respective schools. Table 3 summarises the students' responses.

\begin{tabular}{|c|c|c|}
\hline Students' Responses & F & \% \\
\hline Motivating students to work hard/ rewarding better performance & 68 & 56.2 \\
\hline Provision of conducive environment for learning & 52 & 35.4 \\
\hline Parental involvement in students' performance & 44 & 29.9 \\
\hline Providing role models/motivational speakers & 24 & 16.3 \\
\hline Ensuring teachers and students attend all classes & 16 & 10.8 \\
\hline Provision of learning materials & 14 & 9.5 \\
\hline Encouraging group discussion/ team work & 14 & 9.5 \\
\hline Encouraging student-teacher consultations & 14 & 9.5 \\
\hline Organising contests and academic symposiums & 4 & 2.7 \\
\hline Organising open forums & 4 & 2.7 \\
\hline Benchmarking with high performing schools & 3 & 2.0 \\
\hline
\end{tabular}

Table 3: Students Responses on ways Principals use Ensure Effective Teaching and Learning

The finding in Table 3 shows that students believed that the main ways their principals encouraged them to learn included motivating them to work hard through rewarding better performance $56.2 \%$, provision ofconducive environment for learning $35.4 \%$ and parental involvement in students' learning $29.9 \%$. The least effective method principals used to ensure effective teaching was benchmarking with high performing schools $2.0 \%$. Findings from the open-ended item suggest that school principals made sure that students learning occurred in schools. However, principals were not keen in organising contests/ academic symposiums and benchmarking with high performing schools.

Research question 2:The relationship between students' perception of principals' instructional leadership and academic achievement.

The second research question sought to determine whether there was a significant relationship between the students' perceptions mean scores and academic mean scores for all the fifteen schools for the year 2014.This hypothesis was tested using correlation as applied in the Statistical Package for Social Sciences (SPSS, version 20.0). Since the hypothesis involved test for relationships the researcher adopted Pearson's correlation coefficient. Hypotheses testing 
rules applied in this study are as follows: Alpha value was set at 0.05 . Thus, the decision rule:When $\mathrm{p}$ - value is less than or equal to 0.05 the Null hypothesis is rejected, meaning there is a significant difference between the variables under study. If, however, thep-value is greater than 0.05, we fail to reject the null Hypothesis, meaning there is no significant relationship between the variables being tested. All the assumptions required for test of significance of a correlation were observed. These are: (i) the two variables should be measured at interval or ratio level (ii) there should be linear relationship between the two variables (iii) no significant outliers and (iv) the variables should be approximately normally distributed. All the assumptions were tested before testing the hypothesis and found to comply with Correlation test.

Null Hypothesis $\left(\mathrm{H}_{0}\right)$ 1: There is no significant relationship between the students' perceptions mean scores and academic mean scores for all the fifteen schools for the year 2014.

Analysis of the significance of relationship between students' perception on principals' instructional leadership and school academic performance was generated by running the Pearson's correlation coefficient function through SPSS ver. 20. The researcher correlated the perception mean scores for all the students who participated in the study and the academic mean scores for all the fifteen schools for the year 2014. Results are presented in table 4

\begin{tabular}{|c|c|c|c|}
\hline & school mean & $\begin{array}{c}\text { mean scores: } \\
\text { scores }\end{array}$ & $\begin{array}{c}\text { mrincipal's leadership } \\
\text { prot }\end{array}$ \\
\hline school mean scores & Pearson Correlation & 1 & .000 \\
\hline & Sig. (2-tailed) &. & 147 \\
\hline & $\mathrm{N}$ & 147 & 1 \\
\hline $\begin{array}{c}\text { Principal Instructional } \\
\text { leadership }\end{array}$ & Pearson Correlation & $.614\left(^{* *}\right)$ &. \\
\hline & Sig. (2-tailed) & .000 & 147 \\
\hline & $\mathrm{N}$ & 147 & \\
\hline
\end{tabular}

Table 4: Relationship between Students Perceptions on Principals Instructional Leadership and School Academic Performance ** Correlation Is Significant At The 0.05 Level (2-Tailed).

Based on the results $(r=.614, n=147, p=.000)$ shown in Table 15 the researcher rejected the null hypothesis at alpha 0.05 . Consequently, the research concludes that there is a fairly strong and positive relationship between students' perceptions on principals' instructional leadership and school academic performance which is significant.The results from hypothesis indicate that principals' instructional leadership is an essential activity in ensuring teaching and learning occurs in schools. These findings concur with Mbiti (2009) who attributes the success of any school to the effectiveness of the principal as instructional leader. Thus, school principals have to perform their instructional leadership functions as expected of them so as to influence the academic performance of their schools.

Research Question 3: Challenges Principals Encounter as Instructional Leaders. The third research question sought to establish the challenges school principals were encountering while executing theirinstructional leadership role. The information was sought from the principals. Table 5 presents the findings.

\begin{tabular}{|c|c|c|}
\hline Problem & f & $\mathbf{\%}$ \\
\hline Inadequate finances & 7 & 46.7 \\
\hline Non-cooperation from some members of staff hence dragging the team effort & 7 & 46.7 \\
\hline Handling students with psychological problems-family problems such as divorce, abusive & 4 & 26.7 \\
parents & & \\
\hline Mistrust/ poor communication with stakeholders & 4 & 26.7 \\
\hline Inadequate teaching staff/ unqualified teaching staff & 3 & 20.0 \\
\hline Community's negative attitude towards principal's leadership & 3 & 20.0 \\
\hline Ever-changing curriculum & 1 & 6.7 \\
\hline High expectations from stakeholders & 1 & 6.7 \\
\hline Low entry behaviour of students & 1 & 6.7 \\
\hline
\end{tabular}

Table 5: Problems Principals Face as Instructional Leaders

The main problems which the principals said affected their execution of instructional leadership included inadequate finances to run schools, non-cooperation from some staff, handling students' psychological problems and poor communication with stakeholders. From these findings, it is clear that principals experienced challenges from within the school and outside the school. Majority of principals from Makueni Sub-County highlighted inadequate finances a major challenge they were experiencing. Financial recourses are necessary for the effective running of a school. It is from the financial resources; instructional materials are purchased. In a situation where monetary resources are inadequate, the purchasing of instructional resources such as textbooks and other instructional resources is also affected. The comments from the principals reveal that some parents were not faithful in paying school fees. The harsh climatic conditions in Makueni Sub-County could have had influence in paying of school fees. Thus, the government should increase the funding for schools especial in semiarid and in arid areas to ensure that schools have the required teaching and learning resources and other requirements for the smooth running of the schools.

The academic superiority of any school depends on the principals and the teachers. Principals being the instructional leaders in their schools have the basic responsibility of leading and coordinating teachers towards achieving 
the schools anticipated academic performance. Equally, teachers have a direct accountability towards the students' academic performance in the national examinations. Through classroom instructions, intensive revision with the students, exposing students to several exercises, assignments and examination, teachers largely determine students' academic performance. Thus, teacher-principal cooperation is very important for students' academic success. However, the principals in Makueni Sub-County public secondary schools pointed out that non-cooperation from some members of staff was a major challenge they were facing in their respective schools.

Concerning the school-community relationship, principals pointed out that the experienced negativity from the community. This would mean school-community relationship was not good enough in some schools. Thus, school principal should ensure that they promote school-community relationship. This can be done through organising school-community meetings and activities which will lead the community around the school feel that they own the school.

Further, the principals reported acute shortage of teachers as a challenge they were facing. Shorted of teachers affects the delivery of instructions which sequentially affects students' academic performance. The issue of teachers' shortage is beyond school principal's powers. The government has to thus ensure that all the schools in the republic have the right number of teachers for all subjects. Settings were some schools are understaffed while others overstaffed should not be allowed to prevail.

Any change in curriculum affects the whole school system in terms of teaching and learning resources and teacher preparedness. The principals moreover lamented on the ever-changing curriculum. Such changes affect students' academic performance. The government has to ensure that before implementing any change in the curriculum, schools have the required teaching and learning resources and teachers have been given the training they need to implement the change.

Students discipline is essential for school's academic performance. The school principals pointed out that some students had discipline issues. Indiscipline among students could be one of the bases for low academic performance in most of the school in the Sub-County. In order to curb indiscipline issues, schools should encourage positive school community relationship. This can be possible through strengthening parents-teachers association. Further, guidance and counselling can equally help in correcting students' discipline. Thus, school principals have to ensure that there is a functional guidance and counselling office in their respective schools. They should frequently invite guest speakers in their schools to give talks on life issues. Additionally, the government has to ensure that life skills education programme is fully implemented in schools. For it is through this programme that students can learn skills of managing challenges in their teenage life. Generally, the challenges highlighted by school principals jeopardise their instructional leadership role performance.

Research Question 4: Strategies be put in place to enhance principals' instructional leadershipand students' academic achievement.

The researcher sought suggestions from the students on the strategies, principals can put in placeenhance instructional leadership and improve the academic performance of the students. The responses are shown in Table 6.

\begin{tabular}{|c|c|c|}
\hline Suggestion & f & $\mathbf{\%}$ \\
\hline Students' responses & & \\
\hline Facilitate academic trips/ symposia & 29 & 19.7 \\
\hline Provision of well-equipped learning facilities & 26 & 17.7 \\
\hline Encourage benchmarking programs & 20 & 13.6 \\
\hline Ensure adequate syllabus coverage & 19 & 12.9 \\
\hline Provision of more examination revision materials & 18 & 12.2 \\
\hline Employ enough and qualified teachers & 18 & 12.2 \\
\hline Ensure effective teaching in the school & 18 & 12.2 \\
\hline Firm disciplinary action on non-performers & 18 & 12.2 \\
\hline Re-introduction of tuition/ extra time for preps & 10 & 6.8 \\
\hline Frequent assessments & 9 & 6.1 \\
\hline Continue with the same spirit of working hard & 7 & 4.8 \\
\hline Provide rewards to both teachers and students & 7 & 4.8 \\
\hline Nurture good relationship with students & 6 & 4.1 \\
\hline Advocate for single gendered schools/ boarding schools to avoid indiscipline & 5 & 3.4 \\
\hline Increase entry marks for admission & 4 & 2.7 \\
\hline Provide scholarship programs for needy students & 3 & 2.0 \\
\hline Hold regular interclass discussions & 3 & 2.0 \\
\hline Ensure adherence to school programs & 2 & 1.4 \\
\hline Strengthen top leadership in schools & 1 & 0.7 \\
\hline
\end{tabular}

Table 6: Students' Suggestions on How Principals Can Improve Schools' Performance

The main suggestions raised by the students included: facilitation of academic trips $19.7 \%$, provision of wellequipped learning facilities $17.7 \%$ encouraging benchmarking programs $13.6 \%$, ensuring adequate syllabus coverage $12.9 \%$ and provision of more examination revision materials $12.2 \%$. From the findings, students valued academic trips opportunities of learning from the environment thus breaking the monotony of being in a classroom. Equally, suggestions on provision of well-equipped learning facilities and provision of revision materials implies that students were convinced that without these resources they cannot excel in academics. 
Teaching and learning materials facilitate students' academic performance. Teachers use textbooks and other instructional resources to prepare for the teaching. In circumstances where teaching and learning resources are lacking teacher classroom delivery is affected hence affecting students' academic performance. On the other hand, students use teaching and learning resources to accomplish class assignments and for their private study. If teaching and learning resources are lacking then it is difficult to expose students to several exercises thus, bringing down schools' academic performance. School principals should be vigilant in sourcing for teaching and learning materials. They should organise various activities for instance fund raising to ensure that their schools have enough books. They should also network with organisations which can donate books to the school.

Moreover, students suggested that school principals should make sure that teachers cover their syllabus in time, so as to have effective teaching and frequent assessment. Syllabus coverage is very important to the students' academic performance in the national examination. Syllabus coverage gives students the confidence to sit for national examination knowing that they have learnt what is required of them. However, shallow coverage of the syllabus would weaken the confidence of the students to tackle the examination. School principals have to thus coordinate all the academic departments to make sure that teachers cover their syllabus as required of them. They have to liaise with the heads of departments to ascertain whether teachers cover the syllabus in good time.

On the other hand, students raised concerns on effective teaching. This would imply that teachers were not using a variety of teaching methods to engage the students during the teaching and learning process. Therefore, school principals should encourage teachers to use a variety of teaching methods which clutches the students' attention during classroom instructions. They should further supervise teaching in classrooms to identify those teachers who need professional development courses.

Similarly, the students suggested that they should be given exams frequently. Exposing students to examinations help them to be familiar with different tactics of answering examination questions. This would help them to prepare well for the national examinations. Also, students suggested that good relationship to be nurtured for the purpose was improving academic performance. Furthermore, the students suggested that their principals should organise for benchmarking programs. This would imply that student's value vicarious experiences as a means of improving their performance. In general, the suggestions from the students were pointing to academic excellence of their respective schools.

Conclusions

The study investigated principals' instructional leadership and its relationship to students' academic achievement. Based on the research findings, the following conclusions were drawn: -The principals' instructional leadership roles involve numerous activities which must be accomplished satisfactory to influence students' academic achievement. For a principal to be effective in instructional leadershipproper skills and experiences are required. From the study findings, students who held positive perceptions on principal's instructional leadership had good academic performance, whereas, students who had negative perceptions towards their principals' instructional leadership had low performance.Thus, students' academic achievement to a large extent is determined by their perceptions towards instructional leadership executed by the principals.The positive perception held by students from high performing schools helped them to build confidence that they can perform well in examinations. The study further concludes that there is a positive relationship between principals' instructional leadership and students' academic performance.

To address the challenges emerging from principals' instructional leadership and its relation to academic achievement, there is need for universities to come up with programmes which prepare students taking education in universities to headship positions. Schools should come up with mechanisms that ensure adequate supply of teaching and learning resources.

\section{Recommendations}

From the findings of this study the following recommendations are made:

The principals' instructional leadership skills should be improved in order to help them perform their functions effectively. There is a need for the government in conjunction with universities to develop a training package for principals that will enhance their skills and knowledge in instructional leadership, thus preparing them for their role as they transit from classroom teachers to instructional leaders. The Ministry of Education should set the academic and professional qualifications for secondary school head teachers to be a Master of Education degree in Educational Administration. This will enhance effective instructional leadership in the country.

The Teachers' Service Commission should revise the staffing policy for secondary schools in Kenya to ensure that all the schools in the republic have enough teachers. There should be no school in the republic which is understaffed. The government should increase school funding to ensure that schools are able to purchase instructional materials so as to enhance students' academic performance.

The purpose of class observation as a function is to improve teacher classroom performance and to assist the principal to identify those teachers who need professional development courses. The findings in this study shows that school principals were not keen in supervising teachers during classroom instruction. Class observation is one area that needs to be improved. Thus, school principals should pay attention to in order to improve students' academic performance.Other than the principals and the deputy principals, the senior teachers and HODs should be trained on effective instructional leadership for their assistance is paramount. For instance, they can help in enhancing team work and can also assist in supervisory functions to supplement the principal's roles. 


\section{References}

i. Alexander, R. (2007). Education for all, the Quality Imperative and the Problem of Pedagogy. New Jesy

ii. Blasé,J. \& Blasé, J. (2000). EmpoweringTeachers: What successful principals do (2nd Ed). Thousand Crown.

iii. Creswell, J. W. (2005). Research design: Qualitative, Quantitative, and Mixed Methods Approach (2nd ed.). London: Sage Publications.

iv. Demir, K. (2008). Transformational leadership and collective efficacy: the moderating roles of collaborative culture and teachers' self- efficacy. Egitim Arastirmalari Eurasian Journal of Educational Research, 33, 93-112

v. DiPaola, M. \& Hoy, W.K. (2008). Principals Improving Instruction: Supervision, Evaluation, and Professional Development. Boston: Allyn and Bacon

vi. Fullan, M. (March/ April 2010). The Awesome power of the Principal. National Association of Elementary School Principals, 11-15

vii. GoK (2006). Teachers Service Commission Code of Regulations for Teachers. Government Press. Nairobi

viii. Jones Richard D., Ph.D. 2010; Instructional Leadership Quadrant D Leadership Practices International Centre for Leadership in Education, Inc. International Centre for Leadership in Education, Inc. U.S.A.). Jossey-Bass. http:/ / leadershipeducators.org

ix. Kimosop, M. K. (2002). A Study of the Role of the Heads Teacher in Instructional Supervision in Kabanet and Salawa Division of Baringo Sub-County. Unpublished M. ED thesis Kenyatta University.

x. Kiprotich, K. J. (2011). Effectiveness of Head Teachers' Supervision and Academic Achievement: A Case of Secondary Schools in Bureti District.http:/ / ir-library.ku.ac.ke/ handle/ 123456789/ 554

xi. Mark, H. M. \& Printy, S.M 2003). Principal leading and school performance. An internship educational Administration quarterly 39 (3) 370-397

xii. Mavindu, P. S. (2013).Influence of Principals' Instructional Supervision Practices on Students' Performance in Kenya certificate of secondary examination in trans-Mara west district, KenyaMaster of Education in Educational Administration University of Nairobi

xiii. Mbiti, D. M. (2009). Foundations of school Administration. Nairobi: Oxford University press, Nairobi.

xiv. Mutune, M. S. (2005). The Head Teacher Performance of their Roles as Instructional Leaders in Nakuru Catholic Private Secondary schools. Nakuru Catholic Diocese. Kenya. Unpublished M.Ed., thesis CUEA

xv. Reche, G., Bundi, T., Riungu, J., and Mbugua, Z. (2012). Factors Contributing to Poor Performance in Kenya Certificate of Primary Education in Public Day Primary Schools in Mwimbi Division, Maara District, Kenya. International Journal of Humanities and Social Science.2

xvi. Oyetunyi, C. O. (2006). The Relationship between Leadership Style and School Climate Botswana Secondary Schools. PhD thesis of South Africa. Retrieved December 14, 2012 from http:// www .emory.edu/ htm 